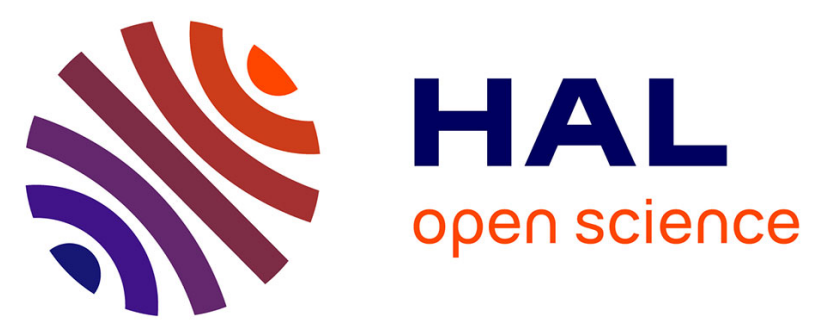

\title{
The chemical exploitation of nickel phytoextraction: An environmental, ecologic and economic opportunity for New Caledonia
}

\author{
Guillaume Losfeld, Vincent Escande, Tanguy Jaffré, Laurent L'Huillier, \\ Claude Grison
}

\section{To cite this version:}

Guillaume Losfeld, Vincent Escande, Tanguy Jaffré, Laurent L'Huillier, Claude Grison. The chemical exploitation of nickel phytoextraction: An environmental, ecologic and economic opportunity for New Caledonia. Chemosphere, 2012, 89 (7), pp.907 - 910. 10.1016/j.chemosphere.2012.05.004 . hal03177627

\section{HAL Id: hal-03177627 \\ https://hal.science/hal-03177627}

Submitted on 23 Mar 2021

HAL is a multi-disciplinary open access archive for the deposit and dissemination of scientific research documents, whether they are published or not. The documents may come from teaching and research institutions in France or abroad, or from public or private research centers.
L'archive ouverte pluridisciplinaire HAL, est destinée au dépôt et à la diffusion de documents scientifiques de niveau recherche, publiés ou non, émanant des établissements d'enseignement et de recherche français ou étrangers, des laboratoires publics ou privés. 


\title{
The chemical exploitation of nickel phytoextraction: An environmental, ecologic and economic opportunity for New Caledonia
}

\author{
Guillaume Losfeld ${ }^{\mathrm{a}}$, Vincent Escande ${ }^{\mathrm{a}, \mathrm{b}}$, Tanguy Jaffréc ${ }^{\mathrm{c}}$, Laurent L'Huillier ${ }^{\mathrm{d}}$, Claude Grison ${ }^{\mathrm{a}, *}$ \\ ${ }^{a}$ Centre d'Ecologie Fonctionnelle et Evolutive, UMR 5175 CNRS, F34293 Montpellier, France \\ ${ }^{\mathrm{b}}$ Agence de l'Environnement et de la Maîtrise de l'Energie, 20 avenue du Grésillé, BP 90406, 49004 Angers cedex 1, France \\ ${ }^{\mathrm{C}}$ UMR AMAP - Laboratoire de Botanique et d'Ecologie Appliquées, Institut de Recherche pour le Développement, Noumea, New Caledonia \\ ${ }^{\mathrm{d}}$ Diversités biologique et fonctionnelle des écosystèmes terrestres, Institut Agronomique néo-Calédonien, Païta, New Caledonia
}

Herein, we explore the outlines of an innovative method based on the chemical recovery of metal-rich biomass produced in phytoextraction technologies. Taking advantage of the adaptive capacity of some New Caledonian plants to hyperaccumulate $\mathrm{Ni}^{2+}$ cations in their aerial parts, this technique is based on the direct use of metals derived from plants as "Lewis acid" catalysts in organic chemistry. Metallic cations contained in New Caledonian nickel hyperaccumulators are recovered through a simple cost-effec-

Keywords:

Hyperaccumulator plants

Biomass

Phytoextraction

Trace metals

Heterogeneous catalysis

Green chemistry tive process and serve the preparation of heterogeneous catalysts used in synthetic transformations allowing access to molecules with high added-value. The design of all processes is in line with the principles of green chemistry; it is adapted to the new economic constraints; it offers a new relevant outlet for metal-rich biomass; and it represents an alternative to non-renewable mineral materials.

\section{Introduction}

New Caledonia is estimated to account for $20-25 \%$ of the world nickel resources. Industrial activities around nickel account for $10 \%$ of the island's gross domestic product and could increase to $30-40 \%$ in the upcoming years (L'Huillier et al., 2010). New Caledonian mines are opencast and before exploitation starts, vegetation, topsoil and upper soil horizons need to be removed. As high-grade ores such as garnierite are becoming scarce, new low-grade lateritic ores are being used with larger excavations. This inevitably leads to increased waste production in ore processing (L'Huillier et al., 2010). Thus the overall impact of mining on ecosystems is serious, with perturbations on water flows, soil erosion, contaminated sediment

* Corresponding author. Address: Centre d'Ecologie Fonctionnelle et Evolutive, UMR 5175, 1919 Route de Mende, F34293 Montpellier cedex 5, France.

E-mail address: claude.grison@cefe-cnrs.fr (C. Grison). transport and bioaccumulation issues (Fernandez et al., 2006; Hedouin et al., 2007; L'Huillier et al., 2010).

Technical feasibility and costs obviously limit soil remediation initiatives: in the case of metal pollution, the conventional method is excavation followed by burial at a waste site for an estimated cost of $\$ 400,000$ per treated hectare (Raskin and Ensley, 2000). Longterm solutions with lower operating-costs are increasingly considered and for metals, phytoremediation appears as a sustainable technique to reclaim land. It is aesthetically more pleasing and boasted better public acceptance where used (Singh et al., 2003). Phytoremediation has a high potential in New Caledonia: the island is a metallophyte flora hotspot with 2153 species (83\% endemics) identified on ultramafic soils (L'Huillier et al., 2010). 27 past experiences in phytoremediation have been reported: these programs mainly considered species selection and agronomic techniques for the development of a sustainable plant cover on mine sites (L'Huillier et al., 2010). Nickel phytoextraction was not considered, because 
a considerable limit of phytoextraction remained: without credible outlets to dispose of metal-rich biomass, phytoextraction only provides little improvement (Sas-Nowosielska et al., 2004). The use of nickel-rich biomass to produce catalysts used in organic syntheses could bring about change and spur the development of phytoextraction in New Caledonia.

\section{Chemical exploitation of metal-rich biomass}

\subsection{Nickel recovery from biomass}

The first step of this project was to develop an efficient method to recover metals from metal-rich biomass. Our main concern was to avoid the use of organic solvents or separation agents as they are hazardous and costly substances. Thus the selection of conditions guided us towards a simple, low-cost and efficient process in accord with the principles of green chemistry. It is also compliant with direct industrial applications (Grison and Escarré, 2011).

Leaves of Psychotria douarrei and Geissois pruinosa were harvested in the South province of New Caledonia. Biomass is dried at $60^{\circ} \mathrm{C}$ (until a stable weight is achieved) and crushed. A thermal treatment at $500{ }^{\circ} \mathrm{C}(5 \mathrm{~h})$ is then applied in order to destroy organic matter. The ashes obtained are treated with hydrochloric acid to finish the destruction of the remaining organic compounds and to convert metallic cations into metal chlorides. In a typical experiment, the reaction mixture was stirred for $2 \mathrm{~h}$ at $60^{\circ} \mathrm{C}$, and then filtered on Celite. The resulting solutions, composed of different metal chlorides, were then concentrated and dry residues could be stored in a stove at $90{ }^{\circ} \mathrm{C}$ for several weeks without undergoing hydrolysis. Table 1 summarizes the main steps of the process and indicates mass variations.

$20 \mathrm{~mL} 1 \mathrm{M} \mathrm{HCl}$ per gram ashes allowed total recovery of the metals present in the plant ashes. Inductively Coupled PlasmaMass Spectrometry (ICPS-MS) analyses were used to determine the composition of the plant extracts obtained. Table 2 exemplifies the composition of the different plant extracts obtained.

\subsection{Use of metal hyperaccumulator biomass in organic chemistry}

In a chemical reaction, a catalyst should be added in small quantities compared to other reagents in order to increase the reaction kinetics. As a general rule, $2-5 \%$ metals are enough to convert $1 \mathrm{~mol}$ of substrate. Using metal hyperaccumulators' biomass we also expected to benefit from the natural polymetallic composition of the plant extracts obtained (Corma and Garcia, 2003). The use of catalysis was established as the 9th of the twelve principles of green chemistry and it is sometimes referred to catalysis as the "foundational pillar" of green chemistry (Anastas et al., 2001). Heterogeneous catalysis presents itself as the latest improvement as it allows catalyst and reagent recycling: active species (metal hyperaccumulators extracts here) are dispersed on a support (montmorillonite K10 here).

The acetylation of anisole (Fig. 1) in heterogeneous catalysis is a witness of the recent evolution of chemistry towards new, more environmentally friendly processes: the reaction has been extensively studied and is a very interesting model to test the efficiency of 'green' Lewis acid supported catalysts. This choice was also

Table 1

Mass obtained from $100 \mathrm{~g}$ dry leaves in each step of the process ( $g \pm$ standard error).

\begin{tabular}{llll}
\hline & Dry leaves & Thermal treatment & Acid treatment \\
\hline P. douarrei & 100 & $11.2( \pm 0.4)$ & $15 \mathrm{~g}( \pm 0.9)$ \\
G. pruinosa & 100 & $14.5( \pm 0.4)$ & $9.8 \mathrm{~g}( \pm 0.5)$ \\
\hline
\end{tabular}

Table 2

Composition (mass percentage) of the plant extracts obtained after treatment.

\begin{tabular}{lllllll}
\hline & $\mathrm{Mg}$ & $\mathrm{Al}$ & $\mathrm{Ca}$ & $\mathrm{Mn}$ & $\mathrm{Fe}$ & $\mathrm{Ni}$ \\
\hline P. douarrei & 1.6 & 0.3 & 6.0 & 0.1 & 0.4 & 11.5 \\
Purified $P$. douarrei & 0.4 & 0.1 & 2.6 & 0.0 & 0.1 & 22.3 \\
G. pruinosa & 7.6 & 0.5 & 12.0 & 0.2 & 0.8 & 7.4 \\
\hline
\end{tabular}

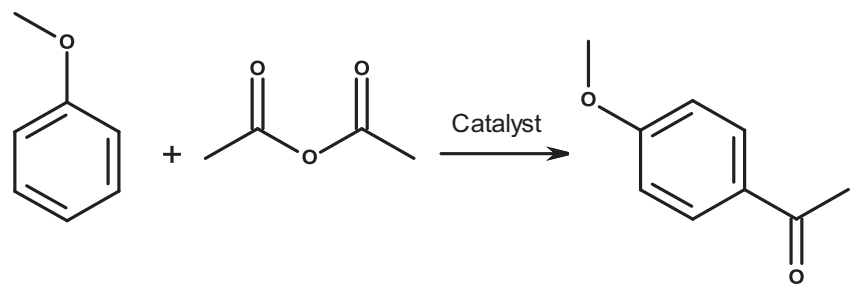

Fig. 1. Acetylation of anisole using acetic anhydride.

motivated by the industrial interest of methoxyacetophenone. Our results using nickel hyperaccumulators extracts supported on montmorillonite $\mathrm{K} 10$ are summarised in Table 3. The increased activity of $\mathrm{NiCl}_{2}$ in heterogeneous catalysis is very interesting considering the advantages of heterogeneous catalysis over homogeneous catalysis (Entry 2-3).

The following features should be noted: (i) The catalysts derived from $P$. douarrei and G. pruinosa were thermally stable and easy to use. (ii) The products could be isolated without work-up. (iii) A simple filtration and thermal activation allowed the green catalyst reuse. (iv) The green catalysts kept a high activity after four recycling (Table 4). (v) The green catalyst activity was much higher than commercial $\mathrm{NiCl}_{2}$. (vi) The green catalyst efficiency was not affected by the formed acetyl moiety, which is a great advantage for Friedel-Crafts acylation. Smaller amounts of green catalysts were required, thus an improved environmental quotient (EQ) was obtained. It also appeared that in heterogeneous catalysis the para/ortho ratio increased dramatically (up to $100 \%$ para isomer). This is due to a rearrangement of the product towards the more thermodynamically stable para compound: it is a positive effect as it avoids purification issues. The best results were obtained using a $P$. douarrei extract after solvent-less purification: the Dow$e x^{T M} M 4195$ (The Dow Chemical Company) ion exchange resin was used to concentrate nickel: $100 \%$ yield was achieved in $6 \mathrm{~h}$ at $70^{\circ} \mathrm{C}$.

This shows that our process is efficient and relevant in today's chemistry context: it performs better than other cutting-edge heterogeneous catalytic systems (Spagnol et al., 1996; Gupta et al., 2008). Moreover, the source of metals should also prove less costly than conventional metals obtained from mining.

\section{Comparison with existing outlets for metal-rich biomass}

To date, two outlets for metal-rich biomass have been thoroughly investigated: 'phytomining' (Brooks et al., 1998), an alternative metal production process developed at the United-Stated Department of Agriculture (USDA) for nickel and bio-energy production (Van Ginneken et al., 2007). Other minor outlets exist, such as compost production to supplement metal deficient soils (Tang et al., 2009) or metal nanoparticle production (Qu et al., 2011).

\subsection{Bioenergy production}

Although comprehensive economic studies showed the potential of bio-energy, a large quantity of biomass is required which leads to restrictions on species used: willow in short-rotation 
Table 3

Results obtained in the acetylation of anisole.

\begin{tabular}{|c|c|c|c|c|c|}
\hline \multirow[t]{2}{*}{ Entry } & \multirow[t]{2}{*}{ Catalyst } & \multicolumn{2}{|c|}{ Catalyst equivalent } & \multicolumn{2}{|l|}{ Yield } \\
\hline & & $\mathrm{NiCl}_{2}$ & Total metal chlorides & $6 \mathrm{~h}(\%)$ & $15 \mathrm{~h}(\%)$ \\
\hline 1 & MK10 $(1.5 \mathrm{~g})$ & - & - & 0 & 0 \\
\hline 2 & Commercial $\mathrm{NiCl}_{2}$ in liquid phase $(1 \mathrm{~g})$ & 4.8 & 4.8 & 44 & 81 \\
\hline 3 & Commercial $\mathrm{NiCl}_{2}$ on $\mathrm{MK} 10(1 \mathrm{~g} / 1.5 \mathrm{~g})$ & 4.8 & 4.8 & 78 & 80 \\
\hline 4 & Crude $P$. douarrei on MK10 $(1 \mathrm{~g} / 1.5 \mathrm{~g})$ & 0.85 & 1.1 & 84 & 85 \\
\hline 5 & Purified $P$. douarrei on MK10 $(1 \mathrm{~g} / 1.5 \mathrm{~g})$ & 1.96 & 2.12 & 100 & 100 \\
\hline 6 & Crude G. pruinosa on MK10 ( $1 \mathrm{~g} / 1.5 \mathrm{~g})$ & 1.26 & 1.37 & 83 & 83 \\
\hline
\end{tabular}

\section{Table 4}

Recycling of the catalyst obtained from P. douarrei extracts supported on montmorillonite K10.

\begin{tabular}{ll}
\hline Run & $\begin{array}{l}\text { Yield obtained using P. douarrei } \\
\text { in the acetylation of anisole (\%) }\end{array}$ \\
\hline First & 84 \\
Second & 85 \\
Third & 86 \\
Fourth & 83 \\
\hline
\end{tabular}

coppice, rapeseed, maize and wheat have been considered (Van Ginneken et al., 2007). Although they do not specifically target any metal, these species were selected for their high annual biomass production and their general tolerance to trace metals. However plant ashes with a low metal content are to be considered as problematic toxic wastes. Moreover such species are not available in New Caledonia: species found on ultramafic soils (including metal hyperaccumulators) are rather slow growing (L'Huillier et al., 2010) and are not suitable for bio-energy production.

\subsection{Nickel phytomining}

In phytomining, nickel hyperaccumulators are considered as a 'bio-ore' and the commercial value of the metal produced could balance the costs involved in the development of phytoextraction. It targets highly contaminated soils and low-grade ores where conventional mining techniques would be too costly. As leaves need to be burned to ashes in the nickel recovery process, a possible production of energy is also possible: expected returns in the best case including nickel and energy production are estimated to $\$ 1311$ per hectare (Brooks et al., 1998). Previous experiences showed that yields could be good enough to foresee commercial applications.

The alternative we propose, which is to use the metal-rich biomass to produce Lewis acid catalysts is conceptually very different from phytomining and could overcome some limits of this technology. It specifically tackles metal contamination regardless of the metal considered and it is also compliant with energy recovery. The end use of metals recovered, which is organic chemistry, allows broader perspectives. Possible valorisation of New Caledonian nickel hyperaccumulators $P$. douarrei and G. pruinosa is considered but zinc hyperaccumulators could also prove very useful. Metallic species are directly obtained in the required state to produce Lewis acid catalysts: herein, nickel chloride is obtained in a simple three steps process from biomass. Compared to currently-used metal production processes followed by metal-chlorides production, the number of steps involved is lesser, and detailed lifecycle analyses should prove the process we describe less costly. Moreover, as exemplified by the acetylation of anisole, purification is not mandatory: although roughly purified $P$. douarrei extracts proved more efficient than untreated plant extracts, a mixture of metallic species still showed increased activity compared to pure commercial nickel chloride.

\section{Conclusion}

Phytoextraction is currently raising much interest as a sustainable method to remediate metal pollution. However, to be fully applicable this innovative technique needs strong incentives including credible outlets for metal-rich biomass. It appears that existing outlets could not give phytoextraction sufficient momentum to lead to a general use of the technology. The alternative we propose, using metal hyperaccumulator plants species as a source of Lewis acid catalysts for organic chemistry could bring about change: it is more adapted to the state of metallic species present in plant tissues; and it could bring extra added value to the metal-rich biomass produced. In terms of organic synthesis, perspectives are various and include hydrochlorinations of alcohols, synthesis of aromatic heterocycle scaffolds, chiral cyclic structures, protections of alcohols and amines, aldolisations, metal catalysed rearrangements and other key syntheses of industrial and fine chemistry.

\section{Acknowledgements}

The authors gratefully acknowledge financial support from the Centre National de la Recherche Scientifique (CNRS), the PIR-CNRS-CEMAGREF INGECOTECH and the ANR (11ECOT01101) and two Grants from the Ecole Polytechnique, Palaiseau and ADEME. They also thank Bruno Buatois for the CEFE platform of chemical analysis, Eddy Petit (IEM/UM2 UMR 5635) for the NMR analysis and Rémi Freydier (Hydrosciences laboratory/AETE platform/UM2) for the ICP-MS analysis.

\section{References}

Anastas, P.T., Kirchhoff, M.M., Williamson, T.C., 2001. Catalysis as a foundational pillar of green chemistry. Appl.Catal., A 221, 3-13.

Brooks, R.R., Chambers, M.F., Nicks, L.J., Robinson, B.H., 1998. Phytomining. Trends Plant Sci. 3, 359-362.

Corma, A., Garcia, H., 2003. Lewis acids: from conventional homogeneous to green homogeneous and heterogeneous catalysis. Chem. Rev. 103, 4307-4365.

Fernandez, J.M., Ouillon, S., Chevillon, C., Douillet, P., Fichez, R., Le Gendre, R., 2006. A combined modelling and geochemical study of the fate of terrigenous inputs from mixed natural and mining sources in a coral reef lagoon (New Caledonia). Mar. Pollut. Bull. 52, 320-331.

Grison, C., Escarré, J., 2011. Use of metal-accumulating plants for the preparation of catalysts that can be used in chemical reactions. International Patents WO 2011/064487 and WO 2011/064462.

Gupta, R., Kumar, V., Gupta, M., Paul, S., Gupta, R., 2008. Silica supported zinc chloride catalyzed acetylation of amines, alcohols and phenols. Indian J. Chem. Sect. B-Org. Chem. Incl. Med. Chem. 47, 1739-1743.

Hedouin, L., Pringault, O., Metian, M., Bustamante, P., Warnau, M., 2007. Nickel bioaccumulation in bivalves from the New Caledonia lagoon: seawater and food exposure. Chemosphere 66, 1449-1457.

L'Huillier, L., Jaffré, T., Wulff, A., 2010. Mines et environnement en NouvelleCalédonie : les milieux sur substrats ultramafiques et leur restauration Editions IAC, Nouméa, Nouvelle-Calédonie.

Qu, J., Yuan, X., Wang, X., Shao, P., 2011. Zinc accumulation and synthesis of ZnO nanoparticles using physalis alkekengi L. Environ. Pollut. 159, 1783-1788.

Raskin, I., Ensley, B.D., 2000. Phytoremediation of toxic metals: using plants to clean up the environment. Wiley, New York: Chichester. 
Sas-Nowosielska, A., Kucharski, R., Malkowski, E., Pogrzeba, M., Kuperberg, J.M., Krynski, K., 2004. Phytoextraction crop disposal - an unsolved problem. Environ. Pollut. 128, 373-379.

Singh, O.V., Labana, S., Pandey, G., Budhiraja, R., Jain, R.K., 2003. Phytoremediation: an overview of metallic ion decontamination from soil. Appl. Microbiol. Biotechnol. 61, 405-412.

Spagnol, M., Gilbert, L., Benazzi, E., Marcilly, C., 1996. Selective etherification of phenylketone cpds. in 4-position|part. suited for the prepn. of 4-methoxyacetophenone from anisole. Rhone Poulenc Chim; Inst Francais Du Petrole; Rhone-Poulenc Chim; Rhodia Chim.
Tang, M., Hu, F., Wu, L., Luo, Y., Jiang, Y., Tan, C., Li, N., Li, Z.g., Zhang, L., 2009. Effects of copper-enriched composts applied to copper-deficient soil on the yield and copper and zinc uptake of wheat. Int. J. Phytoremediat. 11, 82-94.

Van Ginneken, L., Meers, E., Guisson, R., Ruttens, A., Elst, K., Tack, F.M.G., Vangronsveld, J., Diels, L., Dejonghe, W., 2007. Phytoremediation for heavy metal-contaminated soils combined with bioenergy production. J. Environ. Eng Landscape Manage. 15, 227-236. 